\title{
FAKTOR - FAKTOR YANG BERHUBUNGAN DENGAN PERSEPSI TENAGA KESEHATAN TERHADAP VAKSIN COVID-19 DI PUSKESMAS X TAHUN 2020
}

\author{
Denny Wulandari ${ }^{*}$, Ade Heryana ${ }^{2}$, Intan Silviana ${ }^{2}$, Erlina Puspita ${ }^{2}$, Rini $\mathrm{H}^{2}$, Deasy $\mathrm{F}^{2}$ \\ ${ }^{1}$ Peminatan Administrasi dan Kebijakan Kesehatan, Fakultas IImu Kesehatan \\ Universitas Esa Unggul \\ ${ }^{2}$ Bagian Administrasi dan Kebijakan Kesehatan, Fakultas Ilmu Kesehatan Universitas Esa Unggul \\ ${ }^{*}$ Corresponding author: dnwinri@gmail.com
}

\begin{abstract}
The importance of vaccination recommendations for health workers (HCWs) to the public is one of the strongest influencers in vaccination decisions. A preliminary study conducted on ten HCWs concluded that they had different perceptions of the COVID-19 vaccine. Different perceptions are influenced by functional function factors (age, gender, education), sociopsychological factors, and structural factors (knowledge, length of work). The aim of the study was to determine the factors related to the perception of HCWs on the COVID-19 vaccine. This type of research is cross sectional with a quantitative approach. The study was conducted in November 2020 - March 2021. The population and sample were $53 \mathrm{HCWs}$ using total sampling method. Data analysis was performed using univariate and bivariate tests using the chi-square statistical test with $\alpha=0.05$. The conclusion shows that health workers with negative perceptions 22 people (41.5\%), positive perceptions 31\% (58.5\%), young people 24 people (45.3\%), old age 29 people (54.7\%), 33 people (62.3\%), 20 male (37.7\%), 28 people (52.8\%) poor knowledge, 25 good (47.2\%), 14 new workyears (26.4\%) and 39 long years of service (73.6\%). The bivariate analysis showed that there was a relationship between health workers' perceptions of the COVID-19 vaccine with age ( $p$ value $=0.048, P R=2.115)$, gender ( $p$ value $=$ $0.029, P R=2.727$ ), knowledge ( $p$ value $=0.030, P R=2,381$ ). There is no relationship between perceptions of HCWs and years of service ( $p$ value $=0.286, P R=1.592$ ). It is hoped that agencies will provide more socialization and understanding and involve the active role of HCWs so that negative perceptions can be eliminated, considering that vaccine support from HCWs is urgently needed.
\end{abstract}

Keywords: perception of COVID-19 vaccine, age, gender, knowledge, years of service

\section{PENDAHULUAN}

Coronavirus Disease 2019 (COVID19) adalah penyakit menular yang disebabkan oleh Severe Acute Respiratory Syndrome Coronavirus 2 (SARS-CoV-2). ${ }^{1}$ Kebutuhan saat ini adalah mengembangkan vaksin COVID-19 yang aman dan efektif yang dapat memicu respons kekebalan yang tepat untuk menghentikan pandemi COVID-19. Hal ini merupakan prioritas universal untuk menemukan mekanisme pendanaan internasional untuk mendukung pengembangan, pembuatan, dan penimbunan vaksin virus corona. Vaksin COVID-19 sangat dibutuhkan karena penundaan peluncuran vaksin bahkan satu minggu akan menyertai jutaan kematian. ${ }^{2}$ Pentingnya rekomendasi vaksinasi petugas kesehatan kepada publik dalam proses pengambilan keputusan telah didokumentasikan dengan baik dan petugas kesehatan adalah salah satu pemberi pengaruh terkuat dalam keputusan vaksinasi. ${ }^{3}$

Pada dasarnya terdapat tiga jenis sikap kelompok masyarakat terhadap vaksinasi, antara lain kelompok penerima vaksin, kelompok ragu - ragu terhadap vaksin dan kelompok penolak vaksin. ${ }^{4}$ Keragu-raguan biasanya muncul ketika suatu vaksin diperkenalkan kepada publik tentang keefektifan dan potensi keamanannya. Rasa puas tidak tertular, kurangnya kepercayaan terhadap keamanan \& efektivitas sistem layanan vaksin dan vaksinasi, kemudahan mencari layanan dan biaya yang lebih tinggi dari yang diharapkan pada akhirnya dapat mengurangi kemungkinan untuk menerima vaksinasi. ${ }^{3}$ Keragu-raguan vaksin dipengaruhi oleh tingkatan: pengetahuan, sikap dan keyakinan penyedia tentang vaksinasi, faktor organisasi, politik, budaya atau sejarah yang lebih luas. ${ }^{5}$ Krech dan Crutchfield dalam Rakhmat (2007) persepsi di pengaruhi oleh faktor fungsional/ personal dan struktural, faktor situasional. Faktor fungsional/ personal terdiri dari usia, jenis kelamin, kebutuhan, pengetahuan, pendidikan, pekerjaan, penghasilan, masa kerja, motivasi, kepribadian, status social. Fator structural terdiri dari lingkungan, latar belakang budaya, dan agama. Sedangkan faktor situasional terdiri dari petunjuk proksemik dan petunjuk kinesik. ${ }^{6}$ 


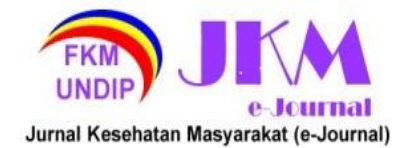

Delapan studi yang dilakukan di antara petugas kesehatan, tiga survei melaporkan tingkat penerimaan vaksin di bawah $60 \%$, dengan tingkat tertinggi di antara dokter di Israel $(78,1 \%)$, penelitian yang berasal dari bagian awal pandemi (Februari dan Maret) di antara perawat di Hong Kong melaporkan tingkat penerimaan vaksin COVID-19 yang rendah $(40,0 \%$ dan $63,0 \%)$ dan tingkat penerimaan vaksin terendah $(27,7 \%)$ dilaporkan di antara petugas kesehatan di Republik Demokratik Kongo (DRC). ${ }^{2}$ Penelitian yang dilakukan di pada Republik Democracy Congo menemukan hanya $28 \%$ dari peserta yang mengatakan bahwa mereka akan mendapatkan vaksin untuk melawan COVID19 jika dan ketika sudah tersedia. Kemauan petugas kesehatan Kongo untuk divaksinasi virus COVID-19 sangat rendah jika dibandingkan dengan studi serupa yang dilakukan di Prancis yang menemukan bahwa $77,6 \%(95 \% \mathrm{Cl} 76,2-79 \%)$ peserta "mungkin setuju" untuk divaksinasi COVID-19. ${ }^{7}$ Selain itu, di Amerika Serikat, berdasarkan survei, hanya sekitar sepertiga (1247, 36\%) responden yang bersedia menerima vaksin COVID-19 segera setelah tersedia pada saat survei. Mayoritas petugas kesehatan tidak yakin atau akan menunggu untuk meninjau data keamanan sebelum divaksinasi (1953, $56 \%$ ). Di antara responden yang ingin menunggu, $11 \%$ ingin menunggu selama 3 bulan, $10 \%$ ingin menunggu selama 6 bulan dan $20 \%$ ingin menunggu minimal 1 tahun. Sebanyak $279(8 \%)$ responden yang tidak mau menerima vaksin sama sekali. ${ }^{8}$

Di dalam negeri, berbagai pendapat terkait vaksinasi banyak disuarakan oleh berbagai lapisan masyarakat, terutama dokter. Suara-suara tersebut pun terbelah dengan argumentasinya masing-masing. Jika salah memahami, dokter bisa terseret arus paham antivaksinasi dan justru menjadi pelopor gerakan ini di masyarakat. Dampaknya adalah kegagalan program pemerintah untuk mengeradikasi penyakit-penyakit infeksi yang seharusnya dapat dicegah dengan vaksin, seperti wabah difteri yang terjadi di akhir 2017. Lebih jauh lagi, beban terhadap anggaran BPJS Kesehatan menjadi bertambah dan pemerintah harus ekstra kerja keras mengatasi wabah yang sebenarnya tidak perlu terjadi. Gerakan antivaksinasi sudah cukup merepotkan banyak pihak, apalagi jika gerakan ini melibatkan tenaga kesehatan. ${ }^{9}$

Petugas kesehatan berpotensi terinfeksi karena pajanan mereka pada pasien
JURNAL KESEHATAN MASYARAKAT (e-Journal)

Volume 9, Nomor 5, September 2021

ISSN: 2715-5617 / e-ISSN: 2356-3346

http://ejournal3.undip.ac.id/index.php/jkm

COVID-19 selama shift kerja, sehingga petugas kesehatan mengalami kondisi yang rentan memicu gangguan psikologis, mereka harus menerapkan langkah-langkah pencegahan dan perlindungan yang memadai, tidak hanya dalam konteks rumah sakit tetapi juga dalam konteks lain. Dengan cara ini, mereka dapat melindungi diri mereka sendiri dan keluarga, kerabat dan teman mereka terhadap resiko tertular penyakit. ${ }^{10}$ Vaksin COVID-19 memang sudah dipersiapkan pemerintah segera, namun tenaga kesehatan (perawat) belum tentu sudah siap menerimanya. ${ }^{11}$ Meskipun memastikan pelatihan yang memadai dalam vaksinologi dalam penyedia layanan kesehatan, hal ini tidak mengatasi masalah terkait keraguan terhadap vaksin. Selain itu, memberikan lebih banyak informasi tentang manfaat vaksinasi dan keamanan kepada tenaga kesehatan tidak mungkin berhasil karena pengetahuan saja tidak cukup untuk mengubah keyakinan yang meragukan vaksin. ${ }^{12} \mathrm{Hal}$ ini bertolak belakang dengan peran tenaga kesehatan sebagai komunikator, motivator, fasilitator, dan konselor. ${ }^{13}$

Puskesmas adalah fasilitas pelayanan kesehatan yang menyelenggarakan upaya kesehatan masyarakat dan upaya kesehatan perseorangan tingkat pertama, dengan lebih mengutamakan upaya promotif dan preventif. Dalam melaksanakan fungsinya, puskesmas berkewajiban melaksanakan kebijakan kesehatan untuk mencapai tujuan pembangunan kesehatan di wilayah kerjanya dan terwujudnya kecamatan sehat. ${ }^{14}$

Salah satu kebijakan yang saat ini harus dicapai adalah cakupan vaksinasi COVID-19 pada tenaga kesehatan. Berdasarkan surat pemberitahuan Kementerian Kesehatan Republik Indonesia Direktorat Jenderal Pencegahan dan Pengendalian Penyakit (2020) mengenai rencana pelaksanaan pemberian imunisasi COVID-19 untuk memutus rantai penularan COVID-19, selain melaksanakan protokol kesehatan secara ketat, juga perlu dilakukan upaya untuk meningkatkan imunitas masyarakat rnelalui kegiatan pemberian imunisasi. Imunisasi COVID-19 akan diberikan pada kelompok rentan usia 18-59 tahun yang terdiri dari tenaga kesehatan, asisten tenaga kesehatan, tenaga penunjang pada fasilitas pelayanan kesehatan, kemudian kelompok proritas lainnya yang ditetapkan berdasarkan kajian epidemiologi dan kebijakan operasional imunisasi COVID-19 seperti petugas 


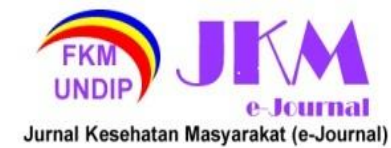

pelayanan publik. Pertanggal 10 Februari 2021 Kemenkes RI (2020) menyatakan total sasaran vaksinasi COVID-19 sebanyak 181.554.465 dengan sasaran sebanyak 1.468.764 pada tenaga kesehatan dengan cakupan vaksinasi tahap 1 sebanyak 969.546 $(66,01 \%)$ dan tahap 2 sebanyak 279.251 $(19,01 \%)$. Berdasarkan laporan Kementrian Kesehatan, cakupan vaksinasi pada tenaga kesehatan belum mencapai $100 \%{ }^{1}$

Untuk mengetahui persepsi tenaga kesehatan terhadap vaksin COVID-19 di Puskesmas $\mathrm{X}$ maka peneliti melakukan studi pendahuluan pada 10 tenaga kesehatan tentang persepsi vaksin COVID-19 yang meliputi 2 perawat (20\%), 5 bidan (50\%), 3 tenaga kesehatan lainnya (30\%). Berdasarkan pertanyaan mengenai persepsi efek samping yang berat yang dapat ditimbulkan oleh vaksin COVID-19, sebanyak 3 orang $(30 \%)$ menyatakan tidak setuju, 5 orang $(50 \%)$ menjawab kurang setuju, 2 orang (20\%) menjawab setuju. Mengenai vaksin tidak akan menimbulkan Kejadian Ikutan Pasca Imunisasi (KIPI) sebanyak $2(20 \%)$ menyatakan tidak setuju, $8(80 \%)$ orang kurang setuju. Kemudian berdasarkan pertanyaan bahwa kandungan vaksin dapat meningkatkan titer imunitas diantaranya 1 orang $(10 \%)$ tidak setuju, 1 orang (10\%) orang menyatakan kurang setuju, dan 7 orang $(70 \%)$ menyatakan setuju dan 1 orang (1\%) menyatakan sangat setuju. Mengenai persepsi tentang vaksin dapat membentuk herd imunity sebanyak 1 orang (10\%) tidak setuju, 2 orang $(20 \%)$ menyatakan kurang setuju, 7 orang (70\%) menyatakan setuju. Kemudian berdasarkan vaksin memperkecil resiko penularan COVID19 didapatkan hasil 4 orang (40\%) tidak setuju, 5 orang $(50 \%)$ setuju, dan 1 orang $(10 \%)$ sangat setuju. Berdasarkan pertanyaan vaksin COVID-19 berdampak menurunkan kasus COVID-19 sebanyak 2 orang (2\%) menyatakan kurang setuju, dan 5 orang $(50 \%)$ menyatakan setuju, dan 3 orang $(30 \%)$ menyatakan sangat setuju. Berdasarkan dosis pertama vaksin efektif sehingga tidak membutuhkan booster sebanyak 2 orang $(20 \%)$ menjawab tidak setuju, 3 orang $(30 \%)$ menjawab kurang setuju, 5 orang (50\%) menjawab setuju. Selanjutnya vaksin COVID19 dapat secara efektif meningkatkan kekebalan pada lansia didapatkan 1 orang $(10 \%)$ orang menyatakan tidak setuju, 6 orang $(60 \%)$ kurang setuju, 2 orang $(20 \%)$ setuju dan 1 orang $(1 \%)$ sangat setuju, kemudian vaksin bagi penyintas COVID-19 diberikan jika
JURNAL KESEHATAN MASYARAKAT (e-Journal)

Volume 9, Nomor 5, September 2021

ISSN: 2715-5617 / e-ISSN: 2356-3346

http://ejournal3.undip.ac.id/index.php/jkm

antibodi tidak tercapai didapatkan 1 orang $(10 \%)$ sangat setuju, 5 orang $(5 \%)$ setuju, 4 orang $(40 \%)$ tidak setuju.

Berdasarkan hasil studi pendahuluan, menunjukkan faktor fungsional yang berbeda pada individu. Selain melalui kuesioner, peneliti juga melakukan studi wawancara dengan tenaga kesehatan yang meliputi dokter, perawat, bidan, dan tenaga kesehatan lainnya. Gambaran dari sepuluh tenaga kesehatan yang yang mempunyai persepsi yang berbeda - beda ditinjau dari usia yaitu $60 \%$ berusia tua ( $\geq 40$ tahun), ditinjau dari jenis kelamin terdiri dari perempuan $70 \%$, ditinjau dari pengetahuan hanya $20 \%$ yang berpengetahuan baik, dan ditinjau dari masa kerja sebanyak $80 \%$ tenaga kesehatan mempunyai masa kerja $\geq 5$ tahun. Dari data yang diperoleh masih ada persepsi yang negatif terhadap vaksin COVID-19. Berdasarkan hasil wawancara dengan responden didapatkan bahwa tenaga kesehatan masih ada keraguan terhadap vaksin COVID-19. Responden menyatakan beberapa teman sejawatnya meskipun sudah mendapat vaksin COVID-19 masih bisa tertular COVID-19. Disisi lain, tenaga kesehatan yang seharusnya tingkat pengetahuan tentang vaksin COVID -19 sudah baik. Puskesmas $X$ sudah melakukan sosialisasi tentang vaksin COVID-19 pada tanggal 25 Januari 2021 kepada seluruh tenaga kesehatan. Walaupun sudah diberikan sosialisasi tentang vaksin COVID-19 namun masih ada keraguan mengenai efek samping, kandungan, efektifitas serta keamanan vaksin COVID-19. Menurut peneliti, persepsi yang berbeda-beda pada tenaga kesehatan di Puskesmas $X$ dapat dipengaruhi oleh faktor fungsional persepsi, hal ini membuat peneliti tertarik untuk meneliti lebih lanjut mengenai Faktor - faktor yang berhubungan dengan persepsi tenaga kesehatan terhadap vaksin COVID-19.

\section{METODE PENELITIAN}

Penelitian ini menggunakan metode kuantitatif dengan menggunakan pendekatan cross sectional untuk memperoleh faktor faktor yang berhubungan dengan persepsi tenaga kesehatan terhadap vaksin COVID-19 di Puskesmas X Tahun 2021. Penelitian ini dilaksanakan pada bulan November 2020 sampai Maret 2021 di Puskesmas X di Jawa Tengah. Populasi dalam penelitian ini adalah seluruh tenaga kesehatan yang ada di Puskesmas $X$ yang berjumlah 53 responden. 


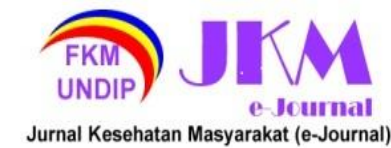

Teknik pengambilan sampel dengan menggunakan total sampling dimana seluruh populasi dijadikan sebagai sampel yaitu sebanyak 53 tenaga kesehatan. Kriteria eksklusi dalam penelitian ini adalah tenaga Kesehatan yang tidak bersedia menjadi responden. Pengumpulan data dilakukan menggunakan data primer melalui kuesioner dalam bentuk google form yang disebarkan melalui aplikasi WhattApp untuk melihat faktor - faktor yang berhubungan dengan persepsi tenaga kesehatan yang meliputi usia, jenis kelamin, pengetahuan, dan masa kerja. Persepsi dibagi menjadi dua yaitu persepsi negatif dan positif dengan nilai cut of point 26,23 (mean) berdasarkan uji Kolmogorov. Hasil uji validitas menggunakan uji product moment dan uji reliabilitas menggunakan
JURNAL KESEHATAN MASYARAKAT (e-Journal)

Volume 9, Nomor 5, September 2021

ISSN: 2715-5617 / e-ISSN: 2356-3346

http://ejournal3.undip.ac.id/index.php/jkm

HASIL

Analisis Univariat

Tabel 1. Distribusi frekuensi persepsi, usia, jenis kelamin, pengetahuan, masa kerja Tenaga Kesehatan Terhadap Vaksin COVID-19 di Puskesmas X Tahun 2020

\begin{tabular}{lccc}
\hline & Variabel & Jumlah & Persentase \\
\cline { 3 - 4 } & & $\mathbf{5 3}$ & $\mathbf{1 0 0} \%$ \\
\hline \multirow{2}{*}{ Persepsi } & Persepsi Negatif & 22 & $41,5 \%$ \\
Usia & Persepsi Positif & 31 & $58,5 \%$ \\
\multirow{2}{*}{ Jenis Kelamin } & Muda & 24 & $45,3 \%$ \\
& Tua & 29 & $54,7 \%$ \\
Pengetahuan & Perempuan & 33 & $62,3 \%$ \\
& Laki - Laki & 20 & $37,7 \%$ \\
Masa Kerja & Kurang Baik & 28 & $52,8 \%$ \\
& Baik & 25 & $47,2 \%$ \\
& Baru & 14 & $26,4 \%$ \\
& Lama & 39 & $73,6 \%$ \\
\hline
\end{tabular}

Berdasarkan tabel 1 hasil penelitian terhadap 53 responden. Diketahui bahwa sebanyak 53 responden tenaga kesehatan yang mempunyai persepsi positif yaitu sebanyak 31 orang $(58,5 \%)$, usia tenaga kesehatan di Puskesmas X Tahun 2020 yaitu usia tua 29 responden $(54,7 \%)$, jenis kelamin tenaga kesehatan di Puskesmas $X$ Tahun 2020 yaitu 33 responden (62,3\%) perempuan, pengetahuan kurang baik sebanyak 28
Cronbrach Alpha menunjukkan seluruh variable yang diuji valid dan reliabel. Pengolahan data dilakukan dengan menggunakan software computer yaitu aplikasi statistik. Analisis univariat bertujuan untuk memperoleh gambaran persepsi tenaga kesehatan terhadap vaksin COVID-19, usia, jenis kelamin, pengetahuan, dan masa kerja. Analisis bivariat dilakukan menggunakan table kontigensi 2x2, uji chi square untuk mengetahui hubungan antara variabel independen (usia, jenis kelamin, pengetahuan, dan masa kerja) dengan variabel dependen (persepsi tenaga kesehatan) berdasarkan nilai p-value, dan nilai prevalensi ratio untuk mengetahui tingkat resiko antara variable independent dengan dependen.

Tabel 2. Uji Statistik faktor - faktor yang berhubungan dengan persepsi Tenaga Kesehatan Terhadap Vaksin COVID-19 di Puskesmas X Tahun 2020

\begin{tabular}{lccccccccc}
\hline \multirow{2}{*}{$\begin{array}{l}\text { Variabel } \\
\text { Independen }\end{array}$} & Kategori & \multicolumn{4}{c}{ Pegatif } & Positif & Total & $\begin{array}{c}\boldsymbol{p} \text { - } \\
\text { value }\end{array}$ & $\begin{array}{c}\text { PR } \\
\mathbf{( 9 5 \% ~ C l )}\end{array}$ \\
\hline Usia & Muda & 14 & $58,3 \%$ & 10 & $41,7 \%$ & 24 & $100 \%$ & 0,048 & 2,115
\end{tabular}




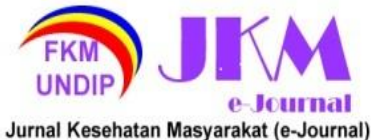

\begin{tabular}{|c|c|c|c|c|c|c|c|c|c|}
\hline & Tua & 8 & $27,6 \%$ & 21 & $72,4 \%$ & 29 & $100 \%$ & & $\begin{array}{c}(1,072- \\
4,173)\end{array}$ \\
\hline Jenis Kelamin & $\begin{array}{c}\text { Perempuan } \\
\text { Laki - Laki }\end{array}$ & $\begin{array}{c}18 \\
4\end{array}$ & $\begin{array}{l}54,5 \% \\
20,0 \%\end{array}$ & $\begin{array}{l}15 \\
16\end{array}$ & $\begin{array}{l}45,5 \% \\
80,0 \%\end{array}$ & $\begin{array}{l}33 \\
33\end{array}$ & $\begin{array}{l}100 \% \\
100 \%\end{array}$ & 0,029 & $\begin{array}{c}2,727 \\
(1,076- \\
6,914)\end{array}$ \\
\hline Pengetahuan & $\begin{array}{c}\text { Kurang } \\
\text { Baik }\end{array}$ & 16 & $57,1 \%$ & 12 & $42,9 \%$ & 28 & $100 \%$ & 0,030 & $\begin{array}{c}2,381 \\
(1,105-\end{array}$ \\
\hline Masa Kerja & $\begin{array}{l}\text { Baik } \\
\text { Baru } \\
\text { Lama }\end{array}$ & $\begin{array}{c}6 \\
8 \\
14\end{array}$ & $\begin{array}{l}24,0 \% \\
57,1 \% \\
35,9 \%\end{array}$ & $\begin{array}{c}19 \\
6 \\
25\end{array}$ & $\begin{array}{l}76,0 \% \\
42,9 \% \\
64,1 \%\end{array}$ & $\begin{array}{l}25 \\
14 \\
39\end{array}$ & $\begin{array}{l}100 \% \\
100 \% \\
100 \%\end{array}$ & 0,286 & $\begin{array}{c}5,131) \\
1,592(0,858 \\
2,953)\end{array}$ \\
\hline
\end{tabular}

Volume 9, Nomor 5, September 2021

ISSN: 2715-5617 / e-ISSN: 2356-3346

http://ejournal3.undip.ac.id/index.php/jkm
Berdasarkan tabel 2 hasil analisis bivariat pada uji chi square menunjukan bahwa ada hubungan antara persepsi tenaga kesehatan terhadap vaksin COVID-19 dengan usia ( $p$ value $=0,048, \quad P R=2,115)$, jenis kelamin $(p$ value $=0,029, \mathrm{PR}=2,727)$, pengetahuan ( $p$ value $=0,030, \mathrm{PR}=2,381$ ). Tidak ada hubungan antara persepsi tenaga Kesehatan dengan masa kerja ( $p$ value $=$ $0,286, \mathrm{PR}=1,592)$.

\section{PEMBAHASAN}

\section{Gambaran Persepsi Tenaga Kesehatan Terhadap Vaksin COVID-19 di Puskesmas X Tahun 2020}

Berdasarkan hasil penelitian persepsi sebagian besar tenaga kesehatan masuk dalam kategori persepsi positif. Dalam kuesioner tenaga kesehatan setuju bahwa vaksin COVID-19 tidak menimbulkan efek samping yang berat dan KIPI, dan tidak setuju apabila vaksin COVID-19 dapat memperkecil kemungkinan untuk tertular COVID-19 dalam jangka panjang dan vaksin COVID-19 memberikan dampak angka kejadian COVID19 menurun secara bertahap.

Menurut penelitian Fu et al. (2020) bahwa persentase petugas kesehatan yang ingin mendapatkan vaksinasi COVID-19 jauh lebih tinggi, namun hampir 20\% petugas kesehatan ragu-ragu tentang vaksinasi COVID-19, yang dapat menjadi penghalang untuk membangun herd imunity. ${ }^{3}$ Menurut Hartono (2016) setiap orang memiliki persepsi yang berbeda, walaupun apa yang dilihatnya sama. Hal ini disebabkan oleh faktor-faktor yang mempengaruhi persepsi seseorang tersebut. ${ }^{15}$
Persepsi merupakan cara pandang seseorang dalam menggambarkan sebuah objek. Pada dasarnya persepsi merupakan sebuah penilaian seseorang terhadap sesuatu. Persepsi seseorang penting karena dengan persepsi akan membentuk perilaku. Perilaku yang akan membentuk sebuah sikap. Ada dua jenis persepsi yaitu persepsi positif dan persepsi negatif. Persepsi negatif terhadap vaksin COVID-19 pada tenaga kesehatan harus dihilangkan. Dampak persepsi vaksin COVID-19 yang negatif pada tenaga kesehatan akan mempengaruhi sukses atau tidaknya program vaksinasi COVID-19 mengingat tenaga kesehatan merupakan tombak utama yang dapat mempengaruhi persepsi masyarakat umum.

Hasil observasi pada penelitian didapatkan sebagian besar tenaga kesehatan yang berpersepsi positif disebabkan tenaga kesehatan mencoba menerima vaksin karena vaksin yang diadakan pemerintah tidak menimbulkan efek samping yang berat dan KIPI, upaya melakukan tindakan preventif yaitu dengan melakukan vaksinasi COVID-19. Selain itu, tenaga kesehatan mendukung program pemerintah untuk mensukseskan program vaksinasi. Program sosialisasi tentang vaksin COVID-19 juga merupakan salah satu faktor yang menyebabkan tenaga kesehatan berpersepsi positif terhadap vaksin COVID-19.

Berdasarkan masalah diatas maka instansi perlu memberikan perhatian, pendekatan dan pengertian akan pentingnya vaksin COVID-19 untuk tenaga kesehatan khususnya yang masih mempunyai persepsi negatif. Tenaga kesehatan juga harus diikutsertakan dan berperan serta dalam menciptakan kepercayaan pada masayarakat karena mengingat kunci sukses vaksinasi ada pada tenaga kesehatan khususnya di tingkat primer yaitu tingkat Puskesmas. 


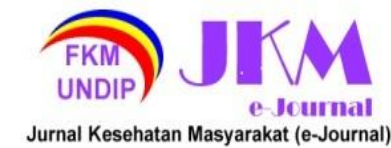

\section{Hubungan antara Usia dengan Persepsi Tenaga Kesehatan Terhadap Vaksin COVID-19}

Berdasarkan hasil penelitian diketahui bahwa sebagian tenaga kesehatan usia tua ( $\geq 40$ tahun). Berdasarkan hasil analisis chi square diketahui ada hubungan antara usia dengan persepsi tenaga kesehatan terhadap vaksin COVID-19. Kelompok usia muda cenderung 2 kali memiliki persepsi negatif terhadap vaksin COVID-19 dibanding kelompok usia tua. Penelitian ini sejalan dengan penelitian yang dilakukan oleh Shekhar et al. (2021) yang berjudul COVID-19 Vaccine Acceptance among Health Care Workers in the United States yang menyatakan bahwa penerimaan vaksin COVID-19 meningkat seiring dengan bertambahnya usia ( $p$ value $<0,001$ ). Pada kelompok usia 18 - 30 tahun hanya $34 \%$ responden yang bersedia menerima vaksin COVID-19 dan 47\% pada kelompok usia > 70 tahun.

Hasil analisis menyatakan bahwa setengah dari tenaga kesehatan berusia tua ( $\geq 40$ tahun). Menurut pengamatan peneliti, penerimaan sumber daya manusia Puskesmas $X$ adalah tenaga kesehatan yang berusia tua. Peneliti berkesimpulan bahwa di usia muda lebih cenderung berpersepsi negatif karena usia muda lebih banyak mengakses informasi dan lebih tidak bijaksana dalam menerima informasi baik itu berita benar maupun hoaks. Tenaga kesehatan yang lebih tua cenderung memiliki kematangan berfikir dan bersikap sehingga lebih mempunyai pemikiran yang lebih baik dan bijaksana dalam menyikapi suatu hal di lingkungan kerja yang dapat membentuk persepsi yang lebih baik dibanding tenaga kesehatan di usia muda.

Usia adalah umur individu yang dihitung mulai saat dilahirkan sampai ulang tahun. Usia mempengaruhi daya tangkap dan pola berpikir, serta perubahan aspek psikis dan psikologis sehingga pengetahuan yang diperoleh semakin baik. ${ }^{16}$ Semakin cukup umur, kematangan dan kekuatan seseorang akan lebih matang dalam berpikir dan bekerja. Semakin tua umur seseorang semakin konstruktif dalam menggunakan koping pengetahuan yang diperoleh. ${ }^{17}$

Berdasarkan masalah diatas maka perlu adanya peran instansi dalam menciptakan kepercayaan terutama persepsi yang positif terhadap vaksin COVID-19 pada petugas kesehatan di usia muda untuk tidak mudah termakan hoaks dan lebih bijaksana
JURNAL KESEHATAN MASYARAKAT (e-Journal)

Volume 9, Nomor 5, September 2021

ISSN: 2715-5617 / e-ISSN: 2356-3346

http://ejournal3.undip.ac.id/index.php/jkm

dalam menerima informasi karena mengingat kunci sukses vaksinasi ada pada tenaga kesehatan khususnya di tingkat primer yaitu tingkat Puskesmas.

\section{Hubungan Jenis Kelamin dengan Persepsi Tenaga Kesehatan Terhadap Vaksin CoviD-19}

Berdasarkan hasil penelitian diketahui bahwa sebagian besar tenaga kesehatan berjenis kelamin perempuan. Berdasarkan hasil analisis chi square diketahui ada hubungan antara jenis kelamin dengan persepsi tenaga kesehatan terhadap vaksin COVID-19. Kelompok jenis kelamin perempuan cenderung 2,7 kali memiliki persepsi negatif terhadap vaksin COVID-19 dibanding kelompok laki - laki. Hal ini sejalan dengan Penelitian Malik et al. (2020) menyatakan bahwa dari 672 , sebanyak 450 responden $(67 \%)$ dapat menerima vaksin COVID-19 jika direkomendasikan untuk mereka. Penerimaan vaksin yang berbeda tersebut dipengaruhi oleh karakteristik demografis yaitu jenis kelamin laki - laki tingkat penerimaannya $72 \%$ lebih banyak dibanding responden wanita. Penelitian Shekhar et al. (2021) menyatakan bahwa ada hubungan antara jenis kelamin tenaga kesehatan di US dengan penerimaan terhadap vaksin COVID-19 ( $p$ value $<0,001)$.

Hasil analisis menyatakan bahwa sebagian besar dari tenaga kesehatan berjenis kelamin perempuan. Menurut peneliti, tenaga kesehatan yang ada di Puskesmas $X$ lebih banyak tenaga bidan. Dimana bidan hanya dapat diisi dengan tenaga kerja perempuan. Menurut hasil penelitian jenis kelamin perempuan lebih banyak yang berpersepsi negatif, karena perempuan lebih cepat menyimpulkan informasi dan percaya akan berita yang didengar dan belum tentu benar akan kebenarannya, sedangkan laki - laki lebih cenderung berfikir baru menyimpulkan dan lebih stabil secara emosi.

Sesuai dengan teori Green yang dikembangkan Rosenstock (1974) dalam Harari \& Legge (2001) yang dikenal dengan Health Belief Model mengatakan bahwa faktor sosiodemografi salah satunya adalah jenis kelamin berpengaruh terhadap persepsi seseorang. ${ }^{18}$ Jenis kelamin tidak langsung mempengaruhi persepsi seseorang tetapi jenis kelamin mempengaruhi salah satu komponen dalam persepsi yaitu afektif atau emosi. Mulyana (2008) menjelaskan bahwa emosi seseorang berpengaruh terhadap persepsi. ${ }^{19}$ 


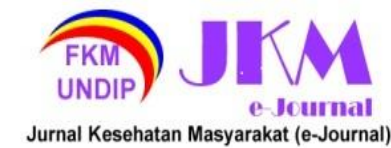

Menurut Rosmalia \& Sriani (2017) jenis kelamin adalah (sex) mengacu pada perbedaan biologis antara laki-laki dan perempuan. ${ }^{20}$ Adanya perbedaan dalam hal perhatian dan pandangan yang menyebabkan jenis kelamin secara social yang mengacu pada peran, perilaku, aktifitas atau budaya tertentu akan mempengaruhi persepsi. ${ }^{19}$ Laki laki cenderung bisa mengendalikan emosi dibandingkan wanita.

Berdasarkan masalah diatas maka perlu adanya diskusi terbuka mengenai vaksin COVID-19 supaya tenaga kesehatan dapat menyaring informasi dengan bijak, khususnya perempuan yang lebih mudah terpengaruh karena perempuan mudah terpengaruh oleh lingkungan dan stimulus lainnya. Pentingnya meluruskan persepsi negatif pada tenaga kesehatan perempuan supaya kebijakan vaksinasi bisa mencapai target yang sudah direncanakan pemerintah.

\section{Hubungan antara Pengetahuan dengan Persepsi Tenaga Kesehatan Terhadap Vaksin COVID-19}

Berdasarkan hasil penelitian diketahui bahwa sebagian tenaga kesehatan mempunyai pengetahuan kurang baik. Berdasarkan hasil analisis chi square diketahui ada hubungan antara pengetahuan dengan persepsi tenaga kesehatan terhadap vaksin COVID-19. Kelompok pengetahuan kurang baik cenderung 2 kali memiliki persepsi negatif terhadap vaksin COVID-19 dibanding kelompok pengetahuan baik. Dalam kuesioner skor terendah adalah pertanyaan nomor 2 yaitu pertanyaan tentang zat yang membantu memperkuat dan memperpanjang respon kekebalan vaksin. Hasil penelitian Ekowati et al. (2017) menunjukkan bahwa terdapat hubungan antara pengetahuan tentang kanker serviks dan persepsi hambatan dari vaksinasi kanker Human Papiloma Virus (HPV). ${ }^{21}$ Faktor - faktor fungsional yang mempengaruhi persepsi disebut kerangka rujukan (frame of reference). Latar belakang pendidikan dan pengalaman memudahkan memahami pengertian atau istilah - istilah yang sesuai dengan latar belakang dan pengalamannya. Hasil analisis penelitian yang dilakukan menunjukkan bahwa mayoritas tenaga kesehatan yang kurang baik hal ini disebabkan banyaknya tenaga kesehatan yang kurang informasi mengenai teori vaksin dari sumber resmi atau jurnal misalnya. Petugas kesehatan umumnya hanya mengetahui point of view dari sebuah vaksin.
JURNAL KESEHATAN MASYARAKAT (e-Journal)

Volume 9, Nomor 5, September 2021

ISSN: 2715-5617 / e-ISSN: 2356-3346

http://ejournal3.undip.ac.id/index.php/jkm

Dan jika ada pelatihan, petugas kesehatan hanya mengingat secara teknis dari sudut pekerjaan saja namun bukan hal yang mendasar atau secara teoritis/ keilmuan. Peneliti mengamati tenaga kesehatan dengan pengetahuan kurang baik lebih cenderung berpersepsi negatif karena tenaga kesehatan tersebut akan lebih cepat menyimpulkan berita tanpa mengecek kembali informasi yang didapatkan dan terburu- buru dalam menyimpulkan suatu informasi.

Pengetahuan merupakan hasil dari tahu, dan ini terjadi setelah orang melakukan pengindraan terhadap suatu obyek tertentu. Pengetahuan merupakan salah satu faktor terpenting yang mengubah kepercayaan kesehatan dan berpotensi menyebabkan perubahan perilaku kesehatan individu. ${ }^{22}$ Pengetahuan sangat dipengaruhi oleh intensitasi perhatian dan persepsi seseorang tehadap objek. Sebagian besar pengatahuan seseorang diperoleh melalui indera pendengaran (telinga), dan indera penglihatan (mata). Pengetahuan seseorang tentang suatu objek mengandung dua aspek, yaitu positif dan negatif. Kedua aspek ini yang akan menentukan sikap seseorang semakin banyak aspek positif yang diketahui, maka akan menimbulkan sikap semakin positif terhadap objek tertentu. ${ }^{16}$ Pengetahuan merupakan salah satu faktor terpenting yang mengubah kepercayaan kesehatan dan berpotensi menyebabkan perubahan perilaku kesehatan individu. Meskipun memastikan pelatihan yang memadai dalam vaksinologi dalam penyedia layanan kesehatan, hal ini tidak mengatasi masalah terkait keraguan terhadap vaksin. Selain itu, memberikan lebih banyak informasi tentang manfaat vaksinasi dan keamanan kepada tenaga kesehatan tidak mungkin berhasil karena pengetahuan saja tidak cukup untuk mengubah keyakinan yang meragukan vaksin. ${ }^{12}$

Berdasarkan masalah diatas maka perlu adanya pengayaan materi atau seminar vaksinasi yang diberikan kepada tenaga kesehatan khususnya yang belum pernah menerima pelatihan vaksinator secara khusus misalnya tenaga kesehatan penunjang lainnya seperti rekam medis, ahli gizi, sanitarian, dll untuk meluruskan persepsi yang negatif.

\section{Hubungan antara Masa Kerja dengan Persepsi Tenaga Kesehatan Terhadap Vaksin COVID-19 \\ Berdasarkan hasil penelitian diketahui} bahwa sebagian besar tenaga kesehatan 


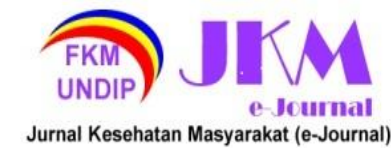

mempunyai masa kerja lama. Berdasarkan hasil analisis chi square diketahui tidak ada hubungan antara masa kerja dengan persepsi tenaga kesehatan terhadap vaksin COVID-19. Kelompok masa kerja baru cenderung 1,6 kali memiliki persepsi negatif terhadap vaksin COVID-19 dibanding kelompok masa kerja lama. Secara teoritis ada hubungan antara masa kerja dengan persepsi, namun hasil penelitian menunjukkan tidak ada hubungan antara masa kerja dengan persepsi. Artinya semakin lama masa kerja tenaga kesehatan tidak ada kaitannya dengan semakin positif atau negatif sebuah persepsi.

Hasil dari penelitian ini menunjukkan masa kerja lama lebih banyak diantara tenaga kesehatan yang ada di Puskesmas $X$, hal ini disebabkan karena sampel umumnya sudah bekerja sebagai tenaga kesehatan kesehatan di tempat lain sebelum menjadi tenaga kesehatan di Puskesmas X.

Ukuran tentang lama waktu atau masa kerja yang telah ditempuh seseorang memahami tugas - tugas suatu pekerjaan dan telah melaksanakan dengan baik. Masa kerja merupakan indikator dari pengalaman kerja. Pengalaman mempengaruhi kecermatan persepsi. Pengalaman tidak selalu lewat proses belajar formal. Pengalaman kita bertambah juga melalui rangkaian peristiwa yang pernah kita hadapi..23 Ketiadaan pengalaman terdahulu dalam menghadapi suatu objek jelas akan membuat seseorang menafsirkan objek tersebut berdasarkan objek semata, atau pengalaman yang mirip. Bila berdasarkan pengalaman suatu objek diperlakukan dengan lazim, kita mungkin akan bereaksi lain terhadap cara baru memperlakukan objek tersebut, berdasarkan persepsi yang lama tersebut. ${ }^{19}$ Pengalaman adalah suatu kejadian yang pernah dialami seseorang dalam berinteraksi dengan lingkungannya. Ada kecenderungan pengalaman yang kurang baik seseorang akan berusaha untuk melupakan, namun jika pengalaman terhadap objek tersebut menyenangkan maka secara psikologis akan timbul kesan yang membekas dalam emosi sehingga menimbulkan sikap positif. ${ }^{16}$

Berdasarkan hasil penelitian, tidak dapat membuktikan hipotesa dengan baik antara masa kerja dengan persepsi tenaga Kesehatan terhadap vaksin COVID-19. Hal ini sejalan dengan penelitian. ${ }^{24}$
JURNAL KESEHATAN MASYARAKAT (e-Journal)

Volume 9, Nomor 5, September 2021

ISSN: 2715-5617 / e-ISSN: 2356-3346

http://ejournal3.undip.ac.id/index.php/jkm

\section{KESIMPULAN}

Berdasarkan hasil penelitian
menunjukan tenaga kesehatan dengan persepsi negatif 22 orang $(41,5 \%)$, persepsi positif $31 \%(58,5 \%)$, usia muda 24 orang $(45,3 \%)$, usia tua 29 orang $(54,7 \%)$, jenis kelamin perempuan 33 orang $(62,3 \%)$, laki laki 20 orang $(37,7 \%)$, pengetahuan kurang baik 28 orang $(52,8 \%)$, baik 25 orang $(47,2 \%)$, masa kerja baru 14 orang(26,4\%) dan lama 39 orang $(73,6 \%)$. Berdasarkan analisa bivariat diperoleh hasil bahwa ada hubungan antara persepsi tenaga kesehatan terhadap vaksin COVID-19 dengan usia ( $p$ value $=0,048, P R=$ $2,115)$, jenis kelamin ( $p$ value $=0,029, P R=$ 2,727 ), pengetahuan ( $p$ value $=0,030, P R=$ 2,381 ). Tidak ada hubungan antara persepsi tenaga kesehatan dengan masa kerja ( $p$ value $=0,286, \mathrm{PR}=1,592)$.

\section{SARAN}

Diharapkan instansi terkait dapat memberikan sosialisasi yang lebih detail dengan metode pendekatan mengenai perspektif dan pemahaman tentang vaksin COVID-19 utamanya mengenai kandungan zat vaksin COVID-19 dapat memperkecil kemungkinan untuk tertular COVID-19 dalam jangka panjang dan vaksin COVID-19 memberikan dampak angka kejadian COVID19 menurun secara bertahap supaya persepsi yang negatif pada tenaga kesehatan dapat dihilangkan mengingat saat ini dukungan vaksin dari tenaga kesehatan sangat dibutuhkan pada era pandemic. Penting bagi Puskesmas $X$ benar-benar memperhatikan setiap tenaga kesehatan yang mempunyai persepsi negatif agar tenaga kesehatan mampu memberikan persepsi positif yang baik kepada masyarakat khususnya masalah vaksinasi COVID -19 karena tenaga kesehatan berperan sebagi educator, motivator bagi masyarakat awam.

\section{DAFTAR PUSTAKA}

1. Kementerian Kesehatan Republik Indonesia Direktorat Jenderal Pencegahan dan Pengendalian Penyakit. Pemberitahuan Rencana Pelaksanaan Pemberian Imunisasi COVID-19. Departemen Kesehatan. 2020; 4-6.

2. Kaur, S. P., \& Gupta, V. COVID-19 Vaccine: A comprehensive status report Simran. 2020.

3. Fu, C., Wei, Z., Pei, S., Li, S., Sun, X., \& Liu, P. Acceptance and preference for COVID-19 vaccination in health-care 


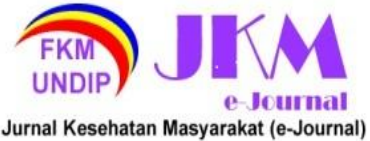

workers (HCWs). MedRxiv. 2020; 2962(548).

4. Heryana, A. Penolakan terhadap vaksinasi. 2020; 1-8.

5. MacDonald, N. E., Eskola, J., Liang, X., Chaudhuri, M., Dube, E., Gellin, B., Goldstein, S., Larson, H., Manzo, M. L., Reingold, A., Tshering, K., Zhou, Y., Duclos, P., Guirguis, S., Hickler, B., \& Schuster, M. Vaccine hesitancy: Definition, scope and determinants. Vaccine. 2015; 33(34), 4161-4164.

6. Rakhmat, J. Psikologi Komunikasi Remaja Rosdakarya; 2007.

7. Mukamba Musenga, E. Acceptability of Vaccination Against COVID-19 Among Healthcare Workers in the Democratic Republic of the Congo. Pragmatic and Observational Research. 2020; 11, 103109.

8. Rahul, Shekhar, M., Sheikh, Abu Bakar, M., \& Subhra Upadhyay, M. IRB approval; 2021.

9. Sundoro, J., Sulaiman, A., Purwadianto, A., \& Wasisto, B. Etika Kedokteran Indonesia. Etika Kedokteran Indonesia. 2017; 1(1), 38.

10. Anmella, G., Fico, G., Roca, A., GómezRamiro, M., Vázquez, M., Murru, A., Pacchiarotti, I., Verdolini, N., \& Vieta, E. Unravelling potential severe psychiatric repercussions on healthcare professionals during the COVID-19 crisis. In Journal of Affective Disorders. 2020; 73(1), 422-424.

11. On, K., Li, K., In, W., Tang, A., Yeung, S., Wong, S., \& Shan, S. International Journal of Nursing Studies Influenza vaccine uptake, COVID-19 vaccination intention and vaccine hesitancy among nurses: A survey. International Journal of Nursing Studies. 2020; 114, 103854.

12. Henrikson, N. B., Opel, D. J., Grothaus, L., Nelson, J., Scrol, A., Dunn, J., Faubion, T., Roberts, M., Marcuse, E. K., \& Grossman, D. C. Physician communication training and parental vaccine hesitancy: A randomized trial. Pediatrics. 2015; 136(1), 70-79.

13. Potter, P. A., Perry, A., Stockert, P., \& Hall, A. Fundamentals of Nursing. 2016..

14. Putri, W. C. W. S., Yuliyatni, P. C. D., Aryani, P., Sari, K. A. K., \& Sawitri, A. A. S. Dasar-dasar Pusat Kesehatan Masyarakat ( Puskesmas ). 2017.

15. Hartono, D. Psikologi Keperawatan. In Pusdik SDM Kesehatan. 2016; 1(1).

Volume 9, Nomor 5, September 2021

ISSN: 2715-5617 / e-ISSN: 2356-3346

http://ejournal3.undip.ac.id/index.php/jkm

16. Wawan, A. dan D. Teori dan Pengukuran Pengetahuan, Sikap, dan Perilaku Manusia. Nuha Medika; 2010.

17. Nursalam. Konsep dan penerapan metodologi penelitian ilmu keperawatan: pedoman skripsi, tesis, dan instrumen penelitian keperawatan (2nd ed.). Salemba Medika; 2008.

18. Harari, P., \& Legge, K. Heinemann themes in physchology: Psychology and health. Heinemann Educational.2001

19. Mulyana, D. Ilmu Komunikasi (12th ed.). Remaja Rosdakarya. 2008

20. Rosmalia, D., \& Sriani, Y. Sosiologi Kesehatan. In Kemenkes RI (1st ed.). Pusat Pendidikan Sumber Daya Manusia Kesehatan; 2017.

21. Ekowati, D., Ari, U., Martini, \& Mateus Sakondamo Adi. Hubungan Pengetahuan Dengan Persepsi Mahasiswi Dalam Penerimaan Vaksinasi Hpv Sebagai Upaya Pencegahan Kanker Serviks. Jurnal Kesehatan Masyarakat (e-Journal). 2017; 5(4), 334-341.

22. Notoatmodjo, S. Pendidikan dan perilaku kesehatan. Rineka Cipta; 2008.

23. Shambodo, Y. Faktor Yang Mempengaruhi Persepsi Khalayak Mahasiswa Pendatang UGM Terhadap Siaran Pawartos Ngayogyakarta Jogja TV. Jurnal Al Azhar Indonesia Seri IImu Sosial. 2020; 1(2), 98.

24. Kabamba, N., Kabamba Ngombe, L., Ngoie Mwamba, G., Banza Ndala, D. B., MbiMiema, J., Luhata Lungoyo, C., Lora Mwimba, B., Cikomola Mwana Bene, A., \& Mukamba Musenga, E. Acceptability of Vaccination Against COVID-19 Among Healthcare Workers in the Democratic Republic of the Congo. Pragmatic and Observational Research. 2020; (11),103109. 